\title{
Research on China's Securities Investment Based on Behavioral Finance
}

\author{
Qizong Yin \\ Nanjing University of Science and Technology, Nanjing 210094, China \\ njutyqz@163.com
}

Keywords: Behavioral finance, herd behavior, empirical analysis.

\begin{abstract}
China's securities market is an emerging market, especially the stock market is still in a primary development stage. Although it has achieved remarkable achievements, it has not yet matured in many aspects, and some new problems have been exposed. One of the outstanding problems is that China's stock market has shown obvious irrational characteristics. This has become a very important issue affecting and restricting the further healthy and stable development of China's stock market. Therefore, investment practices in China's securities market need to consider psychological and behavioral factors. Based on the actual situation of China's securities market, this paper systematically discusses the various psychological and behavioral biases of investors and reveals the behavioral subjects based on behavioral finance theory and the analysis on irrational characteristics of investor behavior. In addition, this paper also demonstrates the herd behavior of China's stock market through empirical analysis.
\end{abstract}

\section{Introduction}

Behavioral finance theory is formed in the context of challenges and doubts about modern financial theory (especially in EMH and CAPM). In the 1950s, the birth of Markowitz's (1952) Mean-Variance Model marked a major breakthrough in finance. Then, under the efforts of Sharp (1964), Lintner (1965), Mossin (1965) and others, it developed into a value equilibrium theory, namely the capital asset pricing model (CAPM). Together with Ross's (1976) arbitrage pricing model, Black\&Scholes' (1972) option pricing model, etc., it forms the theoretical framework of modern finance. However, these ideal models have problems in the subsequent reality test. Many scholars have found that these models have many abnormal phenomena in the statistical process.In the continuous questioning of traditional financial theory and the empirical analysis of reality, behavioral finance has gradually evolved into an emerging branch of finance to analysis the influence of human psychology, behavior and emotion on people's financial decisions, the price of financial products and the development trend of financial markets. The biggest characteristic of behavioral finance is that financial investment and behavioral transactions are regarded as a psychological process. It is believed that traders are not rational people, but there are psychological deviations such as cognition, emotion and decision-making. These psychological deviations, combined with group deviations in the financial market, such as herd behavior, can lead to decision bias in the investment process, causing asset prices to deviate from their intrinsic value, and then asset pricing bias. 
After more than 20 years of rapid development, China's securities market has made great progress, but the market has large fluctuations, high price-earnings ratio, excessive speculation, and serious bubbles. In addition to the defects in the construction of the market system in China, the general and frequent irrational behavior of investors is also an important cause of problems. At the same time, a large number of anomalies such as frequent blacklists, admiring stock reviews and high turnover rates in China's securities market have also challenged standard financial theory, but this has left an active space for behavioral finance theory. China's stock market is generated in the process of China's economic transition. It is more special to use the emerging finance branch, behavioral finance, to study the irrational behavior of investors and various anomalies in the process of economic transition. On the one hand, through the summary analysis of these behaviors, it can show us the behavioral path of irrational investors in China's securities market, reveal the roots and formation mechanism of irrationality in China's securities market, and thus provide design for improving the macro system of China's securities market. Important reference. On the other hand, the introduction of behavioral finance theory also provides new methods and tools for us to analyze and study the behavior of Chinese securities investors, which helps investors to form investment strategies based on behavioral finance theory.

\section{Theoretical analysis}

\subsection{Analysis of the psychological deviation of Chinese securities investors}

The behavior of stock investors in China has a clear tendency to overreact, and the deep roots of this situationIs a behavioral bias caused by various cognitive biases of individual investors, and the result is that the response of the market exceeded the expected range to the information or policies, which aggravated the volatility of the stock market and amplified the irrational bubble of the stock market. I think there are mainly ten kinds of psychological deviations of individual investors in China's stock market:

(1) Overconfident psychological deviation: When making decisions, individual investors in our country often always believe in their own abilities, overestimate their chances of success, or rely too much on the "inside information" they have heard and underestimate the fundamental information such as the accounting statements of listed companies, and When filtering information flow, always pay attention to information that can increase the "confidence complex" and ignore other information. This kind of self-confidence complex often shows excessively frequent transactions in actual investment activities, thereby increasing transaction costs and affecting returns.

(2) Strong "policy dependence" bias: Most investors believe that political, economic factors, securities market policies, and legal factors have the greatest impact on their investment decisions, indicating that investors have an over-reliance on the government and policies. This kind of cognitive bias will cause investors to artificially amplify policy signals, alienating the investment ideas of many investors, and the investment strategy is expressed as "policy arbitrage".

(3) Gambling Psychological Deviation: The gambling characteristics of China's stock market are well known and are dubbed "casinos” by scholars. The existence of gambling has tempted the participation of some "gamblers" investors, and the enthusiastic participation of such investors will inevitably enhance the gambling and speculation of the stock market.

(4) Psychological deviation of wealth: It can be said that many investors are entering the stock market to make a fortune or even to get rich. They are eager to get a good return on investment as soon as possible and put the risk avoidance in a secondary position. Therefore, in the process of stock trading, they often pursue to earn even profits. Such a psychology is bound to enhance the speculative nature of China's stock market, because only the stock market with strong volatility and speculation 
can meet the above requirements of investors.

(5) Psychological Deviation of Excessive Fear: Since a large proportion of individual investors in China's stock market are wage earners, they are not able to withstand risks. When an investment suffers a loss, most individual investors will have a sense of fear, especially if the media or stock market is contributing. The survey shows that the respondents have fears, and investors often have fears. This excessive fear of investors will eventually make the wrong investment decisions.

(6) The banker's complex: Some individual investors in China believe that the stock price is determined by the dealer, which reflects a major misunderstanding of investors, that is, their investment decisions are pinned on the vain banker, and the study of the essential factors of price determination is ignored.

(7) Loss aversion: Loss aversion means that investors value the loss excessively relative to the return. The survey shows that only a few investors in China will adopt a strategy of timely stop loss when the stock is quilted, and most investors will never cut the flesh and wait passively. In the end, when they continue to fall, many investors will sell out their stocks under the control of excessive fear, which intensified market volatility.

(8) Conservative bias: This means that investors are not responding to new things or new information, being comfortable with the status quo, and lacking the courage to accept new challenges, even if new things bring huge benefits. For example, stock trading is quick and easy to trade online, and transaction costs are low, but most investors are more willing to choose on-floor trading.

(9) Selectivity bias: Most investors are most optimistic about blue-chip stocks and technology stocks, based on past performance, and the fact that past performance does not necessarily represent future growth.

(10) Value the difference between stocks and red stocks, and underrate the dividends: Most investors invest in stocks to earn the difference and get bonus shares instead of dividends. Although, because of the poor returns for listed companies in China, cognitive bias has undoubtedly led to investors' short-term investment.

\subsection{The main characteristics of irrational behavior of individual investors in China's stock market}

As an entity of microeconomics, whether it is a market-oriented investor or a senior financial analyst, he always produces various economic behaviors under the motive of satisfying certain needs and pursuing certain interests, and the complexity of his motives determined the irrationality of its behavior. Specifically, the main manifestations of the irrational behavior of individual investors in China are:

(1) The risk diversification is poor: on the whole, the number of stocks held by individual investors in China is less than that of foreign mature stock markets. Therefore, the decentralization of investors in China is obviously not as good as that of foreign mature stock markets.

(2) Trading is too frequent: the turnover rate of major securities markets in the world varies from country to country, and the difference is very far. In contrast, the turnover rate of China's stock market is at the forefront of countries, and this high turnover rate does not seem to slow down.

(3) The investment philosophy is immature: most individual investors in China's stock market have insufficient responses to public information and are overconfident about private information. The mentality is very impetuous, and the entire stock market is full of short-term speculation. The speculative approach of "chasing hotspots and short-term operations" has become mainstream.

(4) The behavior of the herd is very obvious: the herding behavior in the securities market is a special kind of irrational behavior. It means that when the information environment is uncertain, the behavior is influenced by other investors, imitating others' decisions, or excessively rely on the 
overwhelming notion of the market, regardless of the behavior of your own information. The herd behavior in China's securities market is more obvious than the foreign securities market.

\section{Empirical Test of "Herd Behavior" of Chinese Stock Investors}

Since the establishment of China's stock market, it has only been a short period of more than 20 years. The market is still not perfect. The mutual imitation of investors is very common. The follow-up on the stock market and the market are one after another, and the rise and fall are everywhere. This kind of herd behavior not only led to a huge stock price bubble in China's stock market, but also impaired the market operation efficiency, and increased the systemic risk of the market, and the stock market became extremely vulnerable. In view of the fact that herd behavior is so common and influential in financial markets, this paper uses China's investment funds as an example to conduct empirical research on it in order to obtain valuable conclusions. The reason why the investment fund is selected for analysis is because the China Securities Regulatory Commission stipulates that investment funds must publish their relevant information quarterly, so their investment data is easy to obtain and easy to study.

The indicators we use to measure the fund's herd behavior are:

$$
H_{i t}=\frac{\operatorname{Max}\left(H_{i t}^{b}, H_{i t}^{s}\right)}{H_{i t}^{b}+H_{i t}^{s}}
$$

Where $H_{i t}^{b}$ and $H_{\text {it }}^{\mathrm{s}}$ represent the number of funds that buy or sell a stock i for a period of time respectively, $H_{\text {it }}$ represents the proportion of funds that take the same sale and purchase in all funds that buy or sell a stock. $H_{\text {it }}$ changs between 0.5 and 1 , the higher the value, the more obvious the behavior of the herd.This paper selects six Stocks Heavily Held ( CIMC, Guizhou Maotai, Sinopec, Shanghai Automotive, SDIC, China Unicom ) from 2013 to 2015, The analysis of the sale and purchase of an observation period every six months is shown in the table below.

Table 1 the sale and purchase of an observation period every six months

\begin{tabular}{|c|c|c|c|c|c|c|c|}
\hline Stocks & & $\begin{array}{l}\text { the first half of } \\
2013\end{array}$ & $\begin{array}{l}\text { the second half } \\
\text { of } 2013\end{array}$ & $\begin{array}{l}\text { the first half of } \\
2014\end{array}$ & $\begin{array}{l}\text { the second half } \\
\text { of } 2014\end{array}$ & $\begin{array}{l}\text { the first half of } \\
2015\end{array}$ & $\begin{array}{l}\text { the second half } \\
\text { of } 2015\end{array}$ \\
\hline \multirow{3}{*}{ CIMC } & buy & 5 & 3 & 2 & 2 & 3 & 2 \\
\hline & sell & 1 & 0 & 1 & 3 & 1 & 0 \\
\hline & $\mathrm{H}_{\mathrm{it}}$ & 0.83 & 1 & 0.67 & 0.6 & 0.75 & 1 \\
\hline \multirow{3}{*}{ Guizhou Moutai } & buy & 2 & 4 & 1 & 4 & 2 & 5 \\
\hline & sell & 3 & 1 & 3 & 2 & 1 & 2 \\
\hline & $\mathrm{H}_{\mathrm{it}}$ & 0.6 & 0.8 & 0.75 & 0.67 & 0.67 & 0.71 \\
\hline \multirow{3}{*}{ Sinopec } & buy & 7 & 7 & 8 & 7 & 6 & 8 \\
\hline & sell & 0 & 1 & 2 & 2 & 1 & 4 \\
\hline & $\mathrm{H}_{\mathrm{it}}$ & 1 & 0.875 & 0.8 & 0.78 & 0.86 & 0.75 \\
\hline \multirow{3}{*}{$\begin{array}{l}\text { Shanghai } \\
\text { Automotive }\end{array}$} & buy & 9 & 9 & 7 & 3 & 7 & 2 \\
\hline & sell & 3 & 0 & 3 & 2 & 2 & 4 \\
\hline & $\mathrm{H}_{\mathrm{it}}$ & 0.75 & 1 & 0.7 & 0.6 & 0.78 & 0.67 \\
\hline \multirow{3}{*}{ SDIC } & buy & 7 & 6 & 3 & 1 & 2 & 5 \\
\hline & sell & 2 & 0 & 1 & 5 & 4 & 2 \\
\hline & $\mathrm{H}_{\mathrm{it}}$ & 0.78 & 1 & 0.75 & 0.83 & 0.67 & 0.71 \\
\hline \multirow{3}{*}{ China Unicom } & buy & 4 & 5 & 5 & 2 & 7 & 3 \\
\hline & sell & 1 & 2 & 1 & 5 & 2 & 1 \\
\hline & $\mathrm{H}_{\mathrm{it}}$ & 0.8 & 0.71 & 0.83 & 0.71 & 0.78 & 0.75 \\
\hline
\end{tabular}

Then, according to the above data table, calculate the $\mathrm{H}_{\text {it }}$ average of ten stocks separately. The results are shown in the table below. 
Table 2 The results of the $\mathrm{H}_{\mathrm{it}}$ average of ten stocks

\begin{tabular}{|c|c|c|c|c|c|c|}
\hline stocks & CIMC & $\begin{array}{c}\text { Guizhou } \\
\text { Maotai }\end{array}$ & Sinopec & $\begin{array}{c}\text { Shanghai } \\
\text { Automotive }\end{array}$ & SDIC & $\begin{array}{c}\text { China } \\
\text { Unicom }\end{array}$ \\
\hline $\mathrm{H}_{\mathrm{it}}$ & 0.81 & 0.7 & 0.84 & 0.75 & 0.79 & 0.77 \\
\hline
\end{tabular}

As can be seen from the table, the average value of the six stocks is 0.777 , and the median is 0.78 . This shows that when multiple funds buy and sell the same stock, about $80 \%$ of the funds will be in the same direction of buying and selling, as can be seen from the median. It can be seen that on average, China's securities investment funds do have obvious herd behavior for the sale of individual stocks.

\section{Conclusions}

According to the above analysis, there are obvious herd behavior in China's securities investment funds, which has caused excessive fluctuations in stock market prices to some extent. From the perspective of behavioral finance, this irrational behavior mainly stems from the cognitive bias of fund managers in investment, coupled with the institutional defects of the stock market, which further exacerbates this cognitive bias. To this end, my advice is: The first is to improve the external market environment of securities investment funds. We should standardize the company's listing channels, expand the capacity and quality of the market as much as possible, and accelerate financial innovation so that investment funds have more choices and risk hedging tools when choosing a portfolio, creating a better investment environment for investors. The second is to further standardize the information disclosure system. It is necessary to strengthen the timeliness, completeness and accuracy of information disclosure in China's stock market, reduce the cost of various information, and control insider trading. The third is to establish a scientific and applicable fund evaluation system standard, gradually change the concept of investors paying more attention to the returns and paying less attention to the risk, and guide the fund to develop in the direction of establishing a unique investment style. The fourth is to reduce the excessive and frequent intervention of the regulatory layer on the stock market, the regulator should focus on improving the stock price operation mechanism and market information efficiency, and let the market mechanism and investors make rational decisions to determine the stock market.

\section{References}

[1] Li Jingping. Behavioral Finance Theory: A New Analysis Idea [J]. Economic Issues. 2004(01)

[2] Zhuang Jinying. The Relationship between Emotion and Decision Making [J]. Advances in Psychological Science. 2003(04)

[3] Zhang Shengping, Xiong Dehua, Zhang Zheng, Liu Li. The Dilemma of Modern Classical Finance and the Rise of Behavioral Finance [J]. Financial Research. 2003(04)

[4] Zhong Yonghong, Bian Mingshe. Behavioral Finance: Theoretical Review and Practical Application[J]. Economic Issues Exploration. 2003(03)

[5] Weng Xuedong. The Progress of Western Behavioral Finance Theory[J]. Journal of Central University of Finance and Economics. 2003(01)

[6] Ma Hongchao, Zhang Yishan. A Review of Foreign Behavioral Economic Theory Models[J]. Economic History. 2002(09)

[7]Zhan Zhiwei. The Contribution of Canneman and Seiler to Behavioral Economics[J]. Economic Development. 2002(09)

[8]Qian Yingyi. Understanding Modern Economics [J]. Comparison of Economic and Social Systems. 2002(02)

[9]Peng Wenping, Xiao Jihui. Stock Market Policy and Stock Market Volatility [J]. Shanghai Economic Research. 2002(03)

[10]Liu Zhiyang.A Review of Foreign Behavioral Finance Theory [J]. Economic History. 2002(03) 
[11](US) Andrei Shleifer, not an effective market [M]. Renmin University of China Press, 2003

[12]Rao Yulei, Liu Dafeng, Behavioral Finance [M]. Shanghai University of Finance and Economics Press, 2003

[13]Feng Wei, Research on Enterprise Investment Behavior [M]. China Times Economic Publishing House, 2002

[14]Lu Jianqing, Investment Psychology [M]. Dongbei University of Finance and Economics Press, 2000

[15]Yan Hansong, Fund Management Company Investment Strategy [M]. Shanghai University of Finance and Economics Press, 2000

[16](Japan) Lin Kangshi, technical analysis and interpretation [M]. Dongbei University of Finance and Economics Press, 1999 